\title{
HUBUNGAN TINGKAT PENGETAHUAN DENGAN PERILAKU IBU HAMIL TRIMESTER III DALAM PEMANFAATAN BUKU KESEHATAN IBU DAN ANAK (KIA)
}

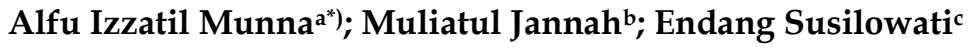 \\ a, b, c Fakultas Kedokteran Prodi Kebidanan; Universitas Islam Sultan Agung Semarang \\ Jalan Raya Kaligawe Km. 4 Po.Box 1054/SM Semarang 50112 - Indonesia
}

\begin{abstract}
Abstrak
Banyak faktor yang mempengaruhi perilaku ibu hamil dalam pemanfaatan buku KIA, salah satunya rendahnya pengetahuan ibu hamil dalam pemanfaatan buku KIA. Data RISKESDAS tahun 2018, bahwa kepemilikan Buku KIA masih dibawah target standar pelayanan $100 \%$.Tujuan dalam penelitian ini adalah untuk mengetahui hubungan tingkat pengetahuan dengan perilaku ibu hamil trimester III dalam pemanfaatan buku KIA di Puskesmas Tlogosari Kulon Kota Semarang. Jenis penelitian ini adalah survei analitik dengan pendekatan cross sectional.Menggunakan teknik accidental sampling, didapatkanjumlah sampel45 responden. Pengumpulan data menggunakan alat ukur kuesioner tingkat pengetahuan dan perilaku ibu hamil trimestester III dalam pemanfaatan buku KIA. Ada hubungan signifikan antara tingkat pengetahuan dengan perilaku ibu hamil $(\mathrm{p}=0,007)$ trimester III dalam pemanfaatan Buku KIA.Simpulan hasil penelitian ini semakin tinggi pengetahuan ibu hamil, sehingga dapat mendeteksi diri sedini mungkin jika terjadi kelainan pada kehamilannya.
\end{abstract}

Kata kunci :Pengetahuan, Perilaku, Pemanfaatan Buku KIA

Abstract

[Relationship between Knowledge Level and Third Trimester Pregnant Mother Behavior in Utilizing Maternal and Child Health Book (KIA) at Tlogosari Kulon Community Health Center Semarang City]Many factors influence the behavior of pregnant women in the use of $\mathrm{MCH}$ books, one of which is the low knowledge of pregnant women in the use of MCH books. RISKESDAS data in 2018, that the ownership of the $\mathrm{MCH}$ Handbook is still below the $100 \%$ service standard target. The purpose of this study was to determine the relationship of the level of knowledge with the behavior of third trimester pregnant women in the use of MCH books at the Tlogosari Kulon Health Center in Semarang City. This type of research is an analytic survey with cross sectional approach. Using accidental sampling technique, the number of samples was 45 respondents. Data collection uses a questionnaire measuring the level of knowledge and behavior of pregnant women trimestester III in the use of the $\mathrm{MCH}$ handbook. There is a significant relationship between the level of knowledge with the behavior $(\mathrm{p}=$ 0,007) of third trimester pregnant women in the use of the $\mathrm{MCH}$ Handbook. Conclusions from the results of this study the higher the knowledge of pregnant women, so they can detect themselves as early as possible if abnormalities occur in pregnancy.

Keyword: Knowledge, Behavior, Utilization of MCH Books.

\section{Pendahuluan}

Ibu dan anak merupakan anggota keluarga yang perlu mendapatkan prioritas dalam

*) Correspondence Author (Alfu Izzatil Munna)

E-mail: alfuna13@gmail.com penyelenggaraan upaya kesehatan, karena ibu dan anak merupakan kelompok rentan terhadap keadaan keluarga dan sekitarnya secara umum. Sehingga penilaian terhadap status kesehatan dan kinerja upaya kesehatan ibu dan anak penting 
untuk dilakukan (Kemenkes RI, 2017; h.105). Keberhasilan upaya kesehatan ibu, di antaranya dapat dilihat dari indikator Angka Kematian Ibu (AKI). AKI merupakan ukuran dalam menilai derajat kesehatan oleh karena itu pemerintah berusaha menurunkan angka kematian ibu dan bayi melalui program-program kesehatan. Kebijakan dan strategi program kesehatan melalui pendekatan yang tepat serta sasaran yang jelas akan mempengaruhi efektivitas dan efisiensi serta pelaksanaan pembangunan kesehatan.

Tingginya Angka Kematian Ibu (AKI) di Kota Semarang yang pada tahun 2016 yaitu 121,5 per 100.000 kelahiran hidup (KH) (Dinkes Kota Semarang, 2016; h.9). Kasus kematian ibu di Puskesmas Tlogosari Kulon tahun 2016 sebanyak 4 kasus dan merupakan urutan pertama kasus kematian ibu di Kota Semarang. Kematian itu terjadi karena perdarahan sebanyak 1 orang, penyakit efulsi pleura sebanyak 2 orang dan preeklampsia berat sebanyak 1 orang.

Dengan adanya masalah tersebut pemerintah membuat keputusan Menteri Kesehatan Republik Indonesia 284/MENKES/SK/III/2004 tentang Buku Kesehatan Ibu dan Anak (KIA). Buku Kesehatan Ibu dan Anak (KIA) merupakan alat untuk mendeteksi secara dini adanya gangguan atau masalah kesehatan ibu dan anak, alat komunikasi dan penyuluhan dengan informasi yang penting bagi ibu dan keluarga dan masyarakat mengenai pelayanan kesehatan ibu dan anak termasuk rujukannya dan paket (standar) pelayanan Kesehatan Ibu dan Anak (KIA), gizi, imunisasi dan tumbuh kembang balita. Sehingga ketika Buku KIA tidak dimanfaatkan dengan baik maka akan sulit melakukan deteksi sejak dini pada ibu dan anak.

Pengetahuan merupakan hasil dari tahu, dan ini terjadi setelah orang melakukan penginderaan terhadap suatu objek tertentu. Penginderaan terjadi melalui panca indra manusia yaitu penglihatan, pendengaran, penciuman, rasa dan raba. Apabila penerimaan perilaku baru atau adopsi perilaku melalui proses yang didasari pengetahuan, kesadaran yang positif, maka perilaku tersebut akan bersifat langgeng daripada perilaku yang tidak didasari oleh pengetahuan akan bersifat sementara atau tidak akan berlangsung lama. Maka dari itu pengetahuan atau kognitif merupakan domain yang sangat penting dalam membentuk tindakan seseorang (Notoatmodjo, 2012; h.6).

Kurangnya pengetahuan ibu tentang penggunaan Buku Kesehatan Ibu dan anak (KIA) yakni masih dianggap hanya sebagai Buku pencatatan kesehatan bagi petugas kesehatan menjadi kendala dalam pembentukan perilaku kesehatan ibu hamil (Oktarina, 2015; h. 147). Peningkatan perilaku sehat ibu hamil juga terus diupayakan untuk mencegah terjadinya kematian ibu. Perilaku sehat ibu hamil sesuai dengan Buku KIA pada Trimester III antara lain penerimaan perubahan fisik dan psikologis trimester III, pemeriksaan kehamilan semester III, seksualitas yang aman dan nyaman, mengatasi ketidaknyamanan ringan, mengetahui tanda bahaya, nutrisi trimester ketiga, menjaga kebersihan umum, menjaga penggunaan obat Fe, mempersiapkan kelahiran janin, menyusui, serta menjadi orangtua.

Dalam penelitian Oktarina 2013 di Kabupaten Bangkalan pengetahuan ibu hamil yang menggunakan Buku Kesehatan Ibu dan Anak (KIA) 87,8 \% kurang, dan kepatuhan dalam menggunakan Buku Kesehatan Ibu dan Anak (KIA) kurang 50\%. Berdasarkan hasil penelitian Kusindijah pengetahuan ibu hamil yang memiliki Buku Kesehatan Ibu dan Anak (KIA) di puskesmas Rangkah Surabaya baik 26,3\% dan 73,7 \% kurang, sedangkan kepemilikan Buku Kesehatan Ibu dan Anak (KIA) terhadap sikap dalam perawatan kehamilan 15,8 \% baik dan 84,2 \% sedang (Kusindijah, 2015; h.47).

Berdasarkan Riset Kesehatan Dasar (RISKESDAS) tahun 2018, hasil analisis menunjukkan bahwa $60 \%$ ibu bisa menunjukkan Buku KIA saat pemeriksaan, sebanyak $10 \%$ tidak dapat menunjukkan Buku KIA, serta terdapat sebanyak 30\% ibu yang sama sekali tidak memiliki Buku KIA. Hal ini menunjukkan bahwa kepemilikan Buku KIA masih dibawah target standar pelayanan yaitu sebesar $100 \%$.

Indikator pengetahuan ibu hamil dalam penelitian ini tentang Buku KIA dapat dilihat dari pengertian, manfaat, dan isi dari Buku KIA, sedangkan perilaku pemanfaatan Buku KIA dilihat dari informasi pelayanan KIA, kehamilan, bersalin, nifas, bayi baru lahir, dan pemantauan perkembangan anak. Berdasarkan wawancara dengan bidan koordinator di Puskesmas Tlogosari Kulon diketahui bahwa cakupan kepemilikan Buku KIA sebesar 95\% atau sudah mencapai target.

Hasil survey pendahuluan di puskesmas Tlogosari Kulon Kota Semarang pada tanggal 21 Mei 2019 ibu hamil kurang mengetahui tentang manfaat Buku KIA. Hal tersebut diperoleh dari hasil wawancara dengan 10 responden yaitu ketika di beri pertanyaan tentang isi dari Buku KIA, 3 dari 10 ibu hamil tidak mengetahui isi dari Buku KIA. Kemudian dari 10 ibu hamil tersebut 
terdapat 5 ibu hamil yang tidak pernah membaca Buku KIA, dan 2 ibu hamil sering lupa membawa Buku KIA saat melakukan pemeriksaan kehamilan.

Dari data pelaporan bulan Januari-Agustus 2019 ibu hamil yang melakukan kunjungan kehamilan sebanyak 1659 ibu hamil dan sebanyak 796 ibu hamil trimester III yang melakukan kunjungan kehamilan.

Berdasarkan hal tersebut maka peneliti ingin mengetahui apakah ada "Hubungan Tingkat Pengetahuan dengan Perilaku Ibu Hamil Trimester III dalam Pemanfaatan Buku Kesehatan Ibu dan Anak (KIA) di Puskesmas Tlogosari Kulon Kota Semarang".

\section{Metode}

Metode penelitian yang digunakan dalam penelitian ini bersifat survei analitik dengan pendekatan cross sectional untuk mempelajari hubungan antara variabel bebas (independent) dan variabel terikat (dependent) dilakukan pengukuran dalam waktu yang sama/sesaat. Penelitian ini tingkat pengetahuan menjadi variabel independent (variabel bebas) dan perilaku ibu hamil trimester
III dalam pemanfaatan buku Kesehatan Ibu dan Anak (KIA) menjadi variabel dependent (variabel terikat).

Lokasi penelitian ini dilakukan di Wilayah Kerja Puskesmas Tlogosari Kulon Kota Semarang, yang dilaksanakan penelitian mulai tanggal 20 September sampai 5 Oktober 2019. Populasi adalah seluruh ibu hamil trimester III yang periksa kehamilan di puskesmas Tlogosari Kulon bulan Agustus berjumlah 83 ibu hamil dan menggunakan teknik pengambilan sampel accidental sampling didapatkan sebanyak $45 \mathrm{ibu}$ hamil.

Pengumpulan data dilakukan dengan menggunakan alat ukur kuesioner tingkat pengetahuan dan perilaku ibu hamil trimestester III dalam pemanfaatan buku KIA. Analisis data menggunakan analisis univariat (distribusi frekuensi), analisis bivariat (chi-square).

\section{Hasil dan Pembahasan}

\section{a. Karakteristik Responden}

Setelah dilakukan penelitian dengan cara menyebarkan kuesioner terhadap 45 responden dapat di distribusikan sebagai berikut:

Tabel 1. Distribusi Frekuensi Karakteristik Responden

\begin{tabular}{lccc}
\hline & Karakteristik & \multicolumn{2}{c}{ Jumlah } \\
\cline { 3 - 4 } Usia & Resiko Rendah & $\mathrm{n}$ & $\%$ \\
& 20-35 Tahun & & \\
& Resiko Tinggi & 38 & 84,4 \\
& <20 Tahun & & \\
& $>35$ Tahun & 4 & 8,9 \\
& & 3 & 6,7 \\
\hline Total & Dasar & 45 & 100,0 \\
\hline Pendidikan & Menengah & 10 & 22,2 \\
& Tinggi & 30 & 66,7 \\
& & 5 & 11,1 \\
\hline Total & Ibu Rumah Tangga & 45 & 100,0 \\
\hline Pekerjaan & Karyawan Swasta & 30 & 66,7 \\
& Wira Swasta & 9 & 20,0 \\
& & 6 & 13,3 \\
\hline Total & & 45 & 100,0 \\
\hline
\end{tabular}

Berdasarkan tabel 1. memperlihatkan bahwa dari 45 responden sebagian besar ibu hamil berusia resiko rendah yaitu usia 20-35 tahun sebanyak 38 orang $(84,4 \%)$. Pendidikan terakhir responden rata-rata yaitu berpendidikan menengah (SMA/SMK/SMU) sebanyak 30 responden (66,7\%). Mayoritas responden mempunyai pekerjaan sebagai ibu rumah tangga sebanyak 30 responden $(66,7 \%)$.

Dalam penelitian ini bahwa rata-rata responden berusia 20-35 tahun.Hasil penelitian ini sejalan dengan penelitian Tri Budi Rahayu
(2017) bahwa dari 48 ibu hamil di wilayah Puskesmas Borobudur Magelang menunjukkan sebagian besar responden berusia 20-25 tahun yaitu sejumlah 38 responden $(79 \%)$.

Menurut Hurlock (2014) semakin cukup umur, tingkat kematangan dan kekuatan seseorang akan lebih matang dalam berpikir dan bekerja (Nursalam, 2013; h.17). Semakin bertambah usia seseorang, semakin berkembang pula daya tangkap dan pola pikir sehinggapengetahuan yang diperoleh semakin baik. Semakin cukup umur maka tingkat 
kematangan dan kekuatan seseorang lebih matang dalam berfikir dan melakukan tindakan.

Pada penelitian ini, ibu hamil yang memeriksakan kehamilan di wilayah kerja Puskesmas Tlogosari Kulon mayoritas berpendidikan menengah yaitu (SMA/SMK/SMU) sebesar (66,7\%), dan masih ditemukan juga ibu hamil yang memiliki tingkat pendidikan dasar yaitu (SD/SMP) sebesar (22,2\%).

Pendidikan yang dimiliki ibu berhubungan dengan banyaknya pengetahuan dan luasnya wawasan yang dimiliki oleh ibu. Pengetahuan tersebut diperoleh dari pendidikan formal yang dijalaninya. Ibu dengan pendidikan menengah diartikan telah mempunyai kemampuan menyerap berbagai informasi yang masuk padanya. Menurut teori Nursalam (2013) pada umumnya makin tinggi pendidikan seseorang, makin mudah menerima informasi sehingga makin banyak pula pengetahuan yang dimiliki. Sebaliknya, pendidikan yang kurang akan menghambat perkembangan seseorang terhadap nilai-nilai yang baru diperkenalkan.

Mayoritas responden mempunyai pekerjaan sebagai ibu rumah tangga sebesar $(66,7 \%)$. Penelitian ini sesuai dengan penelitian Erlina Arlin (2017) bahwa dari 36 responden ibu yang tidak bekerja atau sebagai ibu rumah tangga sebanyak 30 orang $(83,3 \%)$.

Berdasarkan dengan teori Notoadmodjo, (2012; h. 138) menyatakan ibu yang bekerja di sektor formal memiliki akses yang lebih baik terhadap berbagai informasi, termasuk kesehatan. Bekerja umumnya merupakan kegiatan yang menyita waktu. Lingkungan pekerjaan dapat menjadikan seseorang memperoleh pengalaman dan pengetahuan baik secara langsung maupun secara tidak langsung, selanjutnya mempengaruhi pola pikir, cara berpikir, dan sumber informasi.
Hal ini membuktikan bahwa dalam penelitian ini untuk mendapatkan suatu informasi mengenai kehamilan khususnya mengenai pemanfaatan Buku KIA baik ibu yang tidak bekerja atau ibu rumah tangga, karyawan swasta, dan wiraswasta memiliki akses yang sama dalammendapatkan informasi tersebut.

\section{b. Tingkat Pengetahuan}

Tabel 2. Distribusi Frekuensi Tingkat Pengetahuan Responden

\begin{tabular}{lcc}
\hline Tingkat & \multicolumn{2}{c}{ Jumlah } \\
\cline { 2 - 3 } Pengetahuan & $\mathrm{n}$ & $\%$ \\
\hline Baik & 12 & 26,7 \\
Cukup & 20 & 44,4 \\
Kurang & 13 & 28,9 \\
\hline Total & 45 & 100,0 \\
\hline
\end{tabular}

Pada tabel 2. diatas diketahui bahwa pengetahuan ibu hamil trimester III tentang pemanfaatan Buku KIA dalam kategori baik sebanyak 12 responden $(26,7 \%)$, cukup sebanyak 20 responden $(44,4 \%)$, kurang sebanyak 13 responden $(28,9 \%)$.

c. Perilaku Responden

Tabel 3. Distribusi Frekuensi Perilaku Responden

\begin{tabular}{ccc}
\hline Perilaku & \multicolumn{2}{c}{ Jumlah } \\
\cline { 2 - 3 } & $\mathrm{n}$ & $\%$ \\
\hline Positif & 26 & 57,8 \\
Negatif & 19 & 42,2 \\
\hline Total & 45 & 100,0 \\
\hline
\end{tabular}

Tabel 3. diatas diketahui bahwa distribusi perilaku responden dalam pemanfaatan Buku KIA berperilaku positif sebanyak 26 responden $(57,8 \%)$ dan perilaku negatif sebanyak 19 responden $(42,2 \%)$.

Tabel 4. Hubungan Tingkat Pengetahuan dengan Perilaku Ibu Hamil Trimester III dalam Pemanfaatan Buku KIA di Puskesmas Tlogosari Kulon

\begin{tabular}{|c|c|c|c|c|c|}
\hline \multirow{3}{*}{$\begin{array}{c}\text { Tingkat } \\
\text { Pengetahuan } \\
\text { Ibu Hamil }\end{array}$} & \multicolumn{4}{|c|}{ Perilaku } & \multirow{3}{*}{$p$-value } \\
\hline & \multicolumn{2}{|c|}{ Positif } & \multicolumn{2}{|c|}{ Negatif } & \\
\hline & $\mathbf{n}$ & $\%$ & $\mathrm{n}$ & $\%$ & \\
\hline Baik & 10 & 22,2 & 2 & 4,4 & \\
\hline Cukup & 13 & 28,9 & 7 & 15,6 & 0.007 \\
\hline Kurang & 3 & 6,7 & 10 & 22,2 & \\
\hline
\end{tabular}

Berdarkan tabel 4. diatas menunjukkan hasil uji statistik chi square didapatkan nilai $p=0,007$ dimana $p<a \quad(0,007<0,05)$. Sehingga dapat disimpulkan bahwa ada hubungan yang signifikan antara tingkat pengetahuan dengan 
perilaku ibu hamil trimester III dalam pemanfaatan Buku KIA.

Hasil ini sesuai dengan penelitian Nur Hidayatul Ainiyah (2017) yang menyatakan bahwa ada hubungan memanfaatan Buku KIA dengan tingkat pengetahuan dan perilaku kesehatan ibu hamil trimester III di Puskesmas Jagir Surabaya. Diperlukan kesadaran ibu bahwa Buku Kesehatan Ibu dan Anak (KIA) sangat bermanfaat untuk menambah pengetahuan tentang Kesehatan Ibu dan Anak (KIA), sehingga ibu akan mempunyai kebiasaan untuk membaca, memahami isi Buku dan memanfaatkannya dengan menerapkan informasi yang terdapat didalam Buku Kesehatan Ibu dan Anak (KIA), tidak hanya membawa Buku Kesehatan Ibu dan Anak (KIA) setiap kali berkunjung ke fasilitas pelayanan kesehatan.

Hal tersebut sesuai dengan pernyataan Vera Linda Montung (2016) bahwa pengetahuan responden dapat dipengaruhi oleh faktor informasi yang didapat baik secara langsung maupun tidak langsung, penerimaan atau pemahaman serta pengalaman. Salah satu faktor yang mempengaruhi perilaku manusia dari tingkat kesehatan adalah pengetahuan yang merupakan predisposing factor. Pernyataan tersebut didukung oleh Notoadmodjo, (2012) bahwa pengetahuan yang diperoleh dari pengalaman orang lain dapat menentukan seseorang untuk berprilaku tertentu.

Pengetahuan adalah hasil dari tahu, dan ini terjadi setelah orang melakukan penginderaan terhadap suatu objek tertentu. Penginderaan terjadi melalui panca indra manusia yaitu penglihatan, pendengaran, penciuman, rasa dan raba. Proses perilaku tahu yaitu semua kegiatan atau aktifitas manusia baik yang dapat diamati langsung maupun tidak dapat diamati oleh pihak luar, sebelum mengadopsi perilaku baru didalam diri seseorang tersebut terjadi proses (kesadaran, merasa tertarik, menimbang-nimbang, individu mulai mencoba perilaku baru, dan sikapnya terhadap stimulus atau objek) (Nursalam, 2013; h.336).

Pengetahuan seseorang terhadap objek mempunyai intensitas atau tingkatan yang berbeda, dari pengalaman dan penelitian perilaku yang didasari oleh pengetahuan, kesadaran yang positif akan lebih langgeng daripada perilaku yang tidak didasari oleh pengetahuan (Notoatmodjo, 2012; h.138).

Hasil penelitian menujukkan bahwa pengetahuan responden dalam pemanfaatan Buku KIA di Puskesmas Tlogosari Kulon sebagian besar memiliki tingkat pengetahuan cukup sebanyak $(44,4 \%)$, dan perilaku reponden dalam pemanfaatan Buku KIA sebagian besar telah memiliki perilaku positif sebanyak (57,8\%), ibu yang memiliki pengetahuan cukup belum tentu memiliki perilaku positif dalam pemanfaatan Buku KIA, hal tersebut dipengaruhi oleh beberapa faktor seperti usia, pendidikan, dan pekerjaan.

Menurut asumsi peneliti ibu yang berpengetahuan cukup harus memiliki pengetahuan yang umum mengenai kesehatan dan tumbuh kembang anaknya. Hal ini dikarenakan dalam Buku KIA terdapat beberapa istilah yang kurang dimengerti oleh orang awam, sehingga dengan pengetahuan cukup nantinya ibu bisa memanfaatkan Buku Kesehatan Ibu dan Anak (KIA) dengan cara membaca Buku KIA, menerapkan hal-hal yang baik yang diperoleh dalam Buku KIA seperti pemenuhan nutrisi saat masa kehamilan hingga keluarga untuk turut membaca Buku KIA mulai dari masa kehamilan hingga memiliki balita yang digunakan untuk mendeteksi secara dini masalah kesehatan ibu dan anak.

Namun masih adapula ibu hamil yang memiliki tingkat pengetahuan kurang sebanyak (28,9\%). Ibu yang memiliki pengetahuan kurang tentang Buku KIA maka ibu tidak mengetahui bahwa Buku KIA dapat mendeteksi secara dini adanya gangguan dan menjadi sumber informasi mengenai kesehatan ibu dan anak sehingga ibu hanya menganggap Buku tersebut tidak terlalu penting, karena apabila tidak dibawa dalam setiap pemeriksaan kehamilan ibu tetap dapat melakukan pemeriksaan tanpa merasa rugi sama sekali. Adapula ibu yang mendengarkan perkataan petugas kesehatan yang menyuruh ibu untuk datang membawa Buku KIA setiap kali melakukan pemeriksaan, membaca Buku KIA, dan melakukan hal yang berada di Buku KIA membuat ibu memanfaatkan Buku KIA meskipun ibu memiliki pengetahuan kurang.

Begitu pula ibu yang memiliki pengetahuan baik, tidak semua ibu memanfaatkan Buku Kesehatan Ibu dan Anak (KIA) dikarenakan 
ketika ibu sudah memiliki pengetahuan baik, ibu beranggapan bahwa semua yang berada didalam Buku KIA telah diketahui sehingga ibu tidak lagi membaca Buku Kesehatan Ibu dan Anak (KIA) dan ikut mengajak suami/keluarga untuk membaca Buku Kesehatan Ibu dan Anak (KIA).

Tabel 5. Analisis Hubungan Karakteristik dengan Tingkat Pengetahuan Ibu Hamil Trimester III dalam Pemanfaatan Buku KIA di Puskesmas Tlogosari Kulon

\begin{tabular}{|c|c|c|c|c|}
\hline \multirow{2}{*}{ Karakteristik } & \multicolumn{3}{|c|}{ Tingkat Pengetahuan } & \multirow[t]{2}{*}{$p$-value } \\
\hline & Baik & Cukup & Kurang & \\
\hline \multicolumn{5}{|l|}{ Usia } \\
\hline \multicolumn{5}{|l|}{ Resiko Rendah } \\
\hline 20-35 Tahun & $10(26,3 \%)$ & $17(44,7 \%)$ & $11(28,9 \%)$ & $0,933^{*}$ \\
\hline \multicolumn{5}{|l|}{ Resiko Tinggi } \\
\hline$<20+>35$ Tahun & $2(28,6 \%)$ & $3(42,9 \%)$ & $2(28,6 \%)$ & \\
\hline \multicolumn{5}{|l|}{ Pendidikan } \\
\hline Dasar & $0(0,0 \%)$ & $2(20,0 \%)$ & $8(80,0 \%)$ & $0,001^{* *}$ \\
\hline Menengah & $10(33,3 \%)$ & $15(50,0 \%)$ & $5(16,7 \%)$ & \\
\hline Tinggi & $2(40,0 \%)$ & $3(60,0 \%)$ & $0(0,0 \%)$ & \\
\hline \multicolumn{5}{|l|}{ Pekerjaan } \\
\hline Ibu Rumah Tangga & $9(30,0 \%)$ & $13(43,3 \%)$ & $8(26,7 \%)$ & \\
\hline Karyawan Swasta & $2(22,2 \%)$ & $2(22,2 \%)$ & $5(55,6 \%)$ & $0,725^{* *}$ \\
\hline Wira Swasta & $1(16,7 \%)$ & $5(83,3 \%)$ & $0(0,0 \%)$ & \\
\hline
\end{tabular}

Ket :* Uji Mann-Whitney; ** Uji Kruskal-Wallis

Berdasarkan tabel 5. dapat diketahui bahwa karakteristik responden dengan tingkat pengetahuan didapatkan p-value pada karakteristik usia, dan pekerjaan $>0,05$ yang artinya tidak memiliki hubungan yang bermakna karakteristik ibu hamil dengan dengan tingkat pengetahuan ibu hamil trimester III dalam pemanfaatan Buku KIA. Sementara karakteristik pendidikan didapatkan $p$-value yaitu $(0,001<0,05)$ yang artinya memiliki hubungan yang bermakna antara pendidikan dengan tingkat pengetahuan ibu hamil trimseter III.

Tabel 6. Analisis Hubungan Karakteristik dengan Perilaku Ibu Hamil Trimester III dalam Pemanfaatan Buku KIA di Puskesmas Tlogosari Kulon

\begin{tabular}{lccc}
\hline \multicolumn{1}{c}{ Karakteristik } & \multicolumn{2}{c}{ Perilaku } & p-value \\
\cline { 2 - 3 } $\begin{array}{lcc}\text { Usia } \\
\text { Resiko Rendah }\end{array}$ & & Negatif & \\
20-35 Tahun & $22(84,6 \%)$ & $16(84,2 \%)$ & $0,641^{*}$ \\
Resiko Tinggi & & & \\
$<20+>35 T a h u n$ & $4(15,4 \%)$ & $3(15,8 \%)$ & \\
\hline Pendidikan & $3(11,5 \%)$ & $7(36,8 \%)$ & $0,038^{* *}$ \\
Dasar & $19(73,1 \%)$ & $11(57,9 \%)$ & \\
Menengah & $4(15,4 \%)$ & $1(5,3 \%)$ & \\
Tinggi & $17(56,7 \%)$ & $13(43,3 \%)$ & $0,772^{* *}$ \\
\hline Pekerjaan & $5(55,6 \%)$ & $4(44,4 \%)$ & \\
Ibu Rumah Tangga & $4(66,7 \%)$ & $2(33,3 \%)$ & \\
Karyawan Swasta & &
\end{tabular}

$$
\text { Ket :* Uji Fisher; ** Uji Mann-Whitney }
$$

Berdasarkan tabel 6. dapat diketahui bahwa karakteristik responden dengan perilaku didapatkan p-value pada karakteristik usia, dan pekerjaan > 0,05 yang artinya tidak memiliki hubungan yang bermakna karakteristik ibu hamil dengan dengan perilaku ibu hamil trimester III 
dalam pemanfaatan Buku KIA. Sementara karakteristik pendidikan didapatkan $p$-value yaitu $(0,038<0,05)$ yang artinya memiliki

hubungan yang bermakna antara pendidikan dengan perilaku ibu hamil trimseter III.

Sebagian besar usia responden yaitu dalam kategori usia resiko rendah 20-35 tahun sebanyak $(84,4 \%)$. Hasil penelitian Nur Hidayatul Ainiyah (2017) ibu dengan usia 20-35 tahun lebih tertarik memanfaatkan Buku KIA dan selalu membawa Buku KIA sebagai media komunikasi dengan petugas kesehatan.

Daya ingat seseorang salah satunya dipengaruhi oleh umur. Bertambahnya umur seseorang dapat berpengaruh pada pertambahan pengetahuan yang diperolehnya, akan tetapi pada umur tertentu atau menjelang usia lanjut kemampuan penerimaan suatu pengetahuan akan berkurang. Hal tersebut sejalan dengan teori Notoatmodjo (2012), semakin cukup umur maka tingkat kematangan dan kekuatan seseorang lebih matang dalam berfikir dan melakukan tindakan.

Usia merupakan enabling faktor atau faktor pendukung yang mempengaruhi perilaku ibu hamil (Notoatmodjo (2012). Hasil penelitian ini menunjukkan usia merupakan suatu karakteristik individu dan merupakan faktor pendukung saja. Dalam penelitian ini usia tidak memiliki hubungan dengan pengetahuan maupun perilaku, karena ibu hamil yang berumur $<20$ tahun, 20-35 tahun, dan ibu hamil yang berumur $>35$ tahun mempunyai peluang yang sama. Ibu hamil sama-sama rajin melakukan kunjungan ke puskesmas dengan membawa Buku KIA.

Faktor pendidikan lebih berhubungan dengan tingkat pengetahuan maupun perilaku ibu hamil trimester III. Sebagai faktor pendukung pendidikan memiliki hubungan yang bermakna dengan tingkat pengetahuan yakni nilai $p$-value $0,001<0,05$. Pendidikan dengan perilaku nilai $p$ value $0,038<0,05$. Sejalan dengan penelitian Dora Destria (2010; h. 12) ibu hamil dengan tingkat pendidikan dasar (SD, SMP), pendidikan menengah (SMA/SMU/SMK), maupun pendidikan tinggi (D3/PT) sama-sama memiliki pemahaman yang baik terhadap pesan antenatal care yang terdapatdi dalam di Buku KIA. Peneliti lain Amelia Donsu (2016) bahwa ada hubungan yang siginifikan antara pendidikan ibu hamil dengan pengunaan Buku KIA di Puskesmas Sagerat Kecamatan Matuari Kota Bitung.

Dalam penelitian ini mayoritas ibu berpendidikan menengah yaitu
(SMA/SMK/SMU) sebanyak (66,7\%). Pendidikan yang dimiliki ibu berhubungan dengan banyaknya pengetahuan dan luasnya wawasan yang dimiliki oleh ibu. Pengetahuan tersebut diperoleh dari pendidikan formal yang dijalaninya. Ibu dengan pendidikan menengah diartikan telah mempunyai kemampuan menyerap berbagai informasi yang masuk padanya. Notoatmodjo (2012) menyatakan bahwa pada umumnya makin tinggi pendidikan seseorang makin mudah menerima informasi. Semakin banyak informasi yang masuk semakin banyak pula pengetahuan yang didapat tentang kesehatan. Hal ini akan membentuk perilaku yang postif pada ibu terutama perilaku dalam pemanfaatan Buku KIA. Begitupula pendidikan yang rendah juga akan menghambat perkembangan seseorang terhadap nilai-nilai yang baru diperkenalkan.

Berdasarkan uji statistik pekerjaan tidak memiliki hubungan yang bermakna dengan tingkat pengetahuan maupun perilaku ibu hamil trimester III yaitu nilai $p$-value $>0,05$. Pekerjaan dengan tingkat pengetahuan p-value 0,725, pekerjaan dengan perilaku $p$-value 0,772 .

Pekerjaan ibu menunjukkan sebagian besar ibu hamil adalah sebagai ibu rumah tangga sebanyak (66,7\%). Hasil penelitian Tri Budi Rahayu (2017) bahwa pekerjaan tidak sepenuhnya memengaruhi tingkat pengetahuan ibu hamil dalam pemanfaatan Buku KIA. Begitu juga penelitian Emiyanti, dkk (2017) tidak hubungan yang bermakna antara pekerjaan ibu hamil dengan keikutsertaan kelas ibu hamil.

Pekerjaan sebagai ibu rumah tangga tidak dapat menjamin ibu hamil memiliki banyak waktu luang untuk membaca Buku KIA di rumah. Sehingga sebagian besar pengetahuan ibu hamil yang bekerja sebagai ibu rumah tangga dalam penelitian ini hanya dalam kategori cukup. Sementara pekerjaan sebagai karyawan swasta maupun wiraswasta tidak menjamin ibu hamil tidak memiliki waktu untuk membaca Buku KIA.

Menurut teori Wawan \& Dewi (2010; h.1618) bekerja bagi ibu-ibu akan mempunyai pengaruh terhadap kehidupan keluarga, pekerjaan bukanlah sumber kesenangan, tetapi lebih banyak merupakan cara mencari nafkah yang membosankan, berulang dan banyak tantangan. Bekerja pada umumnya merupakan kegiatan menyita waktu. Pekerjaan sebagai faktor pendorong (reinforcing faktor) yang memperkuat perubahan perilaku ibu hamil. 


\section{Simpulan dan Saran}

Simpulan penelitian ini dari hasil analisa terhadap karakteristik Pendidikan dengan tingkat pengetahuan memiliki nilai signifikansi 0,05 , diperoleh nilai $p$ 0,001 $(0,001<0,05)$ dan 0,038 $(0,038<0,05)$, artinya terdapat hubungan karakteristik pendidikan dengan tingkat pengetahuan dan perilaku ibu hamil trimester III dalam pemanfaatan Buku KIA.

Hasil uji statistik chi square didapatkan nilai $p$ $=0,007$ dimana $p<a \quad(0,007<0,05)$. Sehingga ada hubungan yang signifikan antara tingkat pengetahuan dengan perilaku ibu hamil trimester III dalam pemanfaatan Buku KIA.

Saran dalam penelitian ini diharapkan ibu hamil selalu periksa kehamilan secara rutin ke tenaga kesehatan atau datang ke posyandu dengan membawa Buku KIA, mengikuti kegiatan kelas ibu hamil, dan lebih aktif mencari informasi atau bertanya ke petugas kesehatan tentang Buku KIA yang belum dipahami agar dapat meningkatkan pengetahuan. Kepada tenaga kesehatan khususnya bidan dapat memberikan pengarahan yang benar bahwa membaca Buku KIA sangatlah penting bagi kesehatan ibu, meningkatkan penyuluhan tentang fungsi dan pemakaian Buku KIA serta mengikuti penggunaan Buku KIA, melakukan kunjungan rumah apabila ibu tidak periksa sesuai jadwal. Dapat menambah bahan referensi institusi pendidikan yang berhubungan dengan pemanfatan Buku KIA, memfasilitasi mahasiwi dengan mengajarkan cara pengisian Buku KIA. Serta saran kepada peneliti selanjutnya dapat melakukan penelitian lebih lanjut tentang Buku Kesehatan Ibu dan Anak (KIA) dengan metode penelitian yang berbeda, variabel yang berbeda seperti dukungan keluarga dan lingkungan sosial, instrumen pengukuran yang berbeda, serta jumlah populasi dan sampel yang lebih banyak.

\section{Ucapan Terima Kasih}

Terimakasih peneliti ucapkan kepada Puskesmas Tlogosari Kulon Kota Semarang dan Fakultas Kedokteran Prodi Kebidanan Unissula yang telah memberikan dukungannya selama proses penelitian ini sehingga penelitian ini berjalan dengan lancar.

\section{Daftar Pustaka}

Ainiyah, N. (2017) ‘Hubungan Pemanfaatan Buku KIA dengan Tingkat Pengetahuan dan Perilaku Kesehatan Ibu Hamil Trimester III di Puskesmas Jagir Surabaya'.
Arikunto (2013) Prosedur Penelitian. Jakarta: Rineka Cipta.

Arlin, E. (2017) ‘Hubungan Pengetahuan Dengan Sikap Ibu Hamil Tentang Pemanfaatan Buku Kia Di Puskesmas Andowia Kabupaten Konawe Utara'.

Azwar (2014) Sikap Manusia, Teori dan Pengukurannya. Yogyakarta: Pustaka Belajar.

Chandra, B. (2012) Metode Penelitian Kesehatan. Jakarta: EGC.

Dinas, K., Provinsi, K. and Tengah, J. (2019) ‘Evidence Based Dalam Pengambilan Kebijkan Kesehatan'.

Dinas Kesehatan Kota Semarang (2016) 'Profil Kesehatan Kota Semarang'.

Dinkes Jateng (2017) 'Profil Kesehatan Provinsi Jawa Tengah Tahun 2017', 3511351(24).

Destria, D. (2010) 'Faktor-Faktor Yang Berhubungan Dengan Tingkat Pemahaman Ibu Hamil Terhadap Pesan Antenatal Care Yang Terdapat Di Dalam Buku Kia'.

Donsu, A. (2016) 'Hubungan Pendidikan dan Pengetahuan Ibu Hamil dengan Penggunaan Buku Kesehatan Ibu dan Anak (KIA)', 4, p. 2.

Emiyanti, M. Zen Rahfiludin, S. W. (2017) 'Analisis Faktor-Faktor Yang Berhubungan Dengan Keikutsertaan Kelas Ibu Hamil Januari - Juli Tahun 2017 (Studi Di Kecamatan Muara Tembesi Kabupaten Batang Hari Provinsi Jambi)', 5, pp. 801811.

Fajarwati, P. D. (2011) 'Hubungan Tingkat Pengetahuan Ibu Hamil tentang Buku KIA dengan Pemanfaatan Buku KIA di Puskesmas Minggir I Sleman Yogyakarta'.

Hanum, R. (2018) 'Hubungan Pengetahuan Dan Sikap Ibu Hamil Tentang Pemanfaatan Buku KIA Di Puskesmas Namu Ukur.', 1(3).

Hidayat, A. A. (2014) Metode Penelitian Kebidanan dan Teknik Analisis Data. 2nd edn. Jakarta: Salemba Medika.

Kemenkes RI (2015) 'Petunjuk Teknis Penggunaan Buku Kesehatan Ibu dan Anak'.

Kementrian Kesehatan Republik Indonesia (2016) Buku Kesehatan Ibu dan Anak, Buku Kesehatan Ibu dan Anak. doi: 362.198.2.Ind b.

Kesehatan, K. (2018) 'Hasil Utama Riskesdas $2018^{\prime}$.

Kesehatan, K. and Indonesia, R. (2017) Profil Kesehatan Indonesia.

Kesehatan, P. et al. (2014) 'Permenkes RI Nomor 
97 tahun 2014'.

Kusindijah (2012) ‘Hubungan antara kepemilikan Buku kia dengan pengetahuan, sikap dan praktik perawatan kehamilan di wilayah kerja puskesmas rangkah surabaya', I(April), pp. 42-49.

Montung, V. L. et al. (2012) 'Hubungan Pengetahuan Dengan Perilaku Ibu Hamil Trimester III Dalam Persiapan Persalinan', 335, pp. 44-49.

Notoatmodjo, S. (2012) Promosi Kesehatan dan Perilaku Kesehatan. Jakarta: Rineka Cipta.

Notoatmodjo, S. (2018) Metodologi Penelitian Kesehatan. Jakarta: Rineka Cipta.

Oktarina dan Mugeni (2015) 'Hubungan Pengetahuan, Sikap, Kepatuhan Ibu Hamil Dan Ibu Bayi Dalam Pengguna dan Buku KIA di Puskesmas Geger dan Kedundung Kabupaten Bangkalan, Jawa Timur, Tahun 2013 (The Relationships Among Knowledge, Attitude, and Compliance of Gravida (Expectant Mothe', 2013.

Rahayu, T. B. (2017) 'Tingkat Pengetahuan Tentang Pemanfaatan Buku Kesehatan Ibu Dan Anak Berdasarkan Karakteristik Ibu Hamil'.
Semarang, D. K. (2016) 'Profil Kesehatan Kota Semarang'.

Semarang, P. K. K. (2015) ‘Dinas Kesehatan Kota Semarang'.

Setyaningrum, S. S., Arie Wuryanto, SKM, M. K. and Lisa Dwi Astuti, SST, M. K. (no date) 'Gambaran Tingkat Pengetahuan, Sikap Dan Praktik Ibu Hamil Terhadap Penggunaan Buku KIA Sebagai Sumber Referensi Di Desa Leyangan Ungaran'.

Sugiyono (2015) Metode Penelitian Pendidikan (Pendekatan Kuantitatif, Kualitatif dan RED). Bandung: Alfabeta.

Sulistianingsih, A. (2018) 'Gambaran Sumber Informasi Yang Didapatkan Ibu Tentang Pengetahuan Tanda Bahaya Kehamilan Pada Ibu Hamil Di Wilayah Kerja Puskesmas Pringsewu', 7(2), pp. 60-66.

Survei Kesehatan Demografi Indonesia (2015) 'Survei Kesehatan Demografi Indonesia'.

Wardani, I. K. (2018) 'Perilaku Penggunaan Buku Kesehatan Ibu Dan Anak (KIA) Pada Ibu Hamil Di Wilayah Kerja Puskesmas Kecamatan Sragen'.

Wawan, A. D. (2010) Teori dan Pengukuran Pengetahuan, Sikap dan Perilaku Manusia. Yogyakarta: Nuha Medika. 